\title{
Pemodelan Sebaran Pencemaran Tumpahan Minyak di Perairan Cilacap
}

\section{Computational Modeling of Oil Spill Pollution Distribution in Cilacap Seawaters}

\author{
MARDI WIBOWO \\ Balai Teknologi Infrastruktur Pelabuhan dan Dinamika Pantai-BPPT \\ mardi.wibowo@bppt.go.id
}

\begin{abstract}
The Cilacap coastal area plays an important role in recreation, transportation, energy, education or research, residential, and industry. It is also potential for development and potential for pollution especially for oil pollution. That is caused Cilacap has the refinary oil plant and the great port of oil, furthermore it has crowded traffic of ship (both big ship or fishing ships). All of which have a tremendous potential pollute the sea and the surrounding areas. Therefore, it's needed study of oil slick spreading that caused oil spill to formulate early warning and protection action plan for Cilacap coastal area. This study use oil spill model from DHI (Danish Hydraulic Institute) and use software MIKE-21 modul Particle/Spill Analysis. At each scenario, direction and concentration of oil spill is highly varied, its depend on the hydrodynamic condition o sea water. In January the oil spill from the 70 area pier tends to spread upstream S, Donan and around P. Nusakambangan with slick thickness between 0.0001-2.1 mm and oil spill from SPM spread out south of the model domain. In September the oil spill in the 70 area dock spreads upstream of S Donan with slick thickness between 0.001-2.7 mm and oil spills in SPM spread evenly throughout Cilacap waters with slick thickness between 0.001 to $1 \mathrm{~mm}$. The result of this study is very important to plan early warning system and reduce environmental impact of oil spill. Based on comparation tide model data to tide data from field measuring, its known that both of data has no significance differences.
\end{abstract}

Keywords: oil spill spreading, computational modeling, hydrodynamics

\begin{abstract}
ABSTRAK
Kawasan pesisir Cilacap memiliki potensi pengembangan wilayah yang sangat besar. Namun demikian, kawasan ini juga mempunyai ancaman terhadap pencemaran tumpahan minyak, terutama disebabkan oleh aktivitas kapal, kebocoran pipa, single point mooring (SPM), dan kapal nelayan yang dapat merusak ekosistem perairan Cilacap dan sekitarnya. Karena itu, kajian persebaran minyak diperlukan untuk menyusun tindakan peringatan dini dan perlindungan kawasan pesisir Cilacap. Dalam kajian ini dilakukan pemodelan penyebaran minyak dengan menggunakan model tumpahan minyak dari DHI (Danish Hydraulic Institute) dan perangkat lunak MIKE-21 modul Particle/Spill Analysis. Berbagai parameter inputan data diperoleh dari data sekunder dan hasil survei lapangan pada 8-14 Januari dan 1016 September 2012. Terdapat empat model skenario penyebaran disusun dan hasil akhir divalidasi dengan hasil pengukuran. Sebagai hasil, arah persebaran dan konsentrasi tumpahan minyak untuk tiap skenario sangat bervariasi dari waktu ke waktu tergantung pada kondisi hidrodinamika perairan yang ada. Pada bulan Januari tumpahan minyak dari dermaga area 70 cenderung menyebar ke hulu S. Donan dan di sekitar P. Nusakambangan dengan ketebalan slick antara 0,0001-2,1 mm dan tumpahan minyak dari SPM tersebar ke selatan keluar ari domain model. Pada bulan September tumpahan minyak di dermaga area 70 tersebar $\mathrm{ka}$ arah hulu S Donan dengan ketebalan slick antara 0,001-2,7 mm dan tumpahan minyak di SPM tersebar merata ke seluruh wialayah perairan Cilacap dengan ketebalan slick antara 0,001-1 mm. Hasil kajian ini sangat penting sebagai dasar perencanaan upaya peringatan dini tumpahan minyak dan meminimalisasi dampak tumpahan minyak. Validasi data pasang surut hasil pemodelan dan pengukuran lapangan dari Intergovernmental Oceanographic Commission (IOC) menunjukkan tidak adanya perbedaan yang nyata.
\end{abstract}

Kata kunci: persebaran tumpahan minyak, pemodelan komputasi, hidrodinamika 


\section{PENDAHULUAN}

\subsection{Latar Belakang}

Kawasan pesisir Cilacap saat ini mengalami perkembangan yang sangat cepat dan dinamis terutama dalam aspek perubahan fisik lahan maupun dari aspek perkembangan kegiatan perkotaan. Selain itu kawasan ini memiliki kelengkapan keragaman kondisi fisik, biologi, tipe garis pantai, dan bentuk penggunaan lahan yang bervariasi. Dari 23 kecamatan yang ada, sebanyak 12 di antaranya mempunyai wilayah pesisir dengan total panjang garis pantai sekitar $100 \mathrm{~km}$. Wilayah pesisir Cilacap juga memiliki jasa lingkungan yang sangat penting karena wilayah ini dimanfaatkan sebagai tempat rekreasi, media tranportasi, sumber energi, sarana pendidikan atau penelitian, pemukiman, industri, dan sebagai sarana pertahanan keamanan.

Selain potensi-potensi pengembangan tersebut, kawasan ini juga mempunyai potensi ancaman yang besar untuk mengalami pencemaran terutama pencemaran minyak. Hal tersebut dikarenakan selain Cilacap mempunyai kilang minyak dan pelabuhan minyak yang besar, juga merupakan jalur lalu lintas laut yang cukup ramai (baik kapal besar maupun kapal nelayan), yang kesemuanya sangat berpotensi mencemari laut dan pesisir di sekitarnya.

Berdasarkan data yang dihimpun dari berbagai sumber, selama kurun waktu 1989 -2015 terdapat sebanyak 17 kasus pencemaran minyak yang terjadi di perairan Cilacap, 13 diantaranya disebabkan kecelakaan kapal dan 4 kasus akibat kebocoran pipa. Pencemaran minyak ini dapat menyebabkan kerugian berupa kerusakan ekosistem dan penurunan kegiatan sosial ekonomi lautan(1).

Sebagai contoh kasus tumpahan minyak di Cilacap adalah kasus kecelakaan kapal tanker King Fisher yang membawa 600.000 barrel minyak mentah pada April tahun 2000 yang mencemari perairan Teluk Cilacap, Jawa Tengah. Sepanjang 10 kilometer mulai dari Area 70 di wilayah Kelurahan Cilacap, Pantai Teluk Penyu Pantai Tegal Kamulyan - Lengkong(2). Pada tanggal 10 September 2004 jam 05.30 WIB kapal MT Lucky Lady yang membawa seria crude (minyak ringan $300 \mathrm{API}$ ) dari Brunei Darussalam untuk pasokan kilang minyak UP IV Cilacap menabrak karang pada posisi 070 45' 28" S/ 1090
03' 27" T (perairan Teluk Penyu) yang mengakibatkan sobek pada lambung pada bagian kanan kapal yaitu kompartemen no. 1 lebar \pm 2 $\mathrm{cm}$, panjang $\pm 4 \mathrm{~m}$ sehingga terjadi kebocoran crude yang tumpah ke laut sebanyak $5300 \mathrm{~m}^{3(3)}$.

Kebocoran kapal tanker Palu Sipat pada April 2008 yang menumpahkan 18.500 kilo liter bahan bakar minyak jenis Middle Fuel Oil (MFO) atau minyak bakar ${ }^{(4)}$. Kemudian pada Oktober 2010 Kapal Tanker Alissa XVII menjadi penyebab tumpahan minyak Midle Fuel Oil (MFO) di perairan Teluk Penyu Cilacap. Akibat tumpahan minyak tersebut ribuan nelayan tradisional yang biasa beroperasi di Jalur 1 (0-3 mil) khawatir, pencemaran perairan itu akan berdampak terhadap rusaknya sumber hayati laut di kawasan tersebut. Di beberapa lokasi sudah mulai tampak ikan-ikan yang mati, terapung di permukaan laut. Belasan bangkai burung, diantaranya burung belibis, ditemukan di beberapa tempat di sepanjang pantai yang tercemar minyak mentah itu. Selain itu juga akan sangat mengganggu keberlanjutan ekosistem mangrove di kawasan Segara Anakan yang sangat kaya akan keanekaragaman hayati ${ }^{5}$.

Kasus tumpahan minyak lain adalah tumpahan minyak akibat kebocoran pipa dari kapal tanker Alenza XXVII di $30 \mathrm{~km}$ lepas pantai Cilacap yang sedang membongkar minyak Arabic Light Crude Oil (ALC) yang terjadi pada awal Juli 2011(6). Dan yang paling terakhir terjadi pada awal September 2011, dimana terjadi tumpahan minyak di sekitar dermaga CIB 2 Pertamina UP IV Cilacap, dimana terjadi kebocoran pipa pembuangan kapal MT Medelin Atlas yang sedang bongkar muat Arabian Light Crude Oil $(A L C)^{(7)}$. Kasus tumpahan minyak yang terakhir terjadi pada tanggal 20 Mei 2015 yaitu tumpahan minyak Marine Fuel Oil (MFO) dari kebocoran Kapal MT Martha Petrol yang memuat produk MFO 180 sebanyak 24.000 kiloliter dan MFO 380 sebanyak 5.000 kiloliter(8). $^{(8)}$

Tumpahan minyak di laut dapat menyebar luas dengan cepat karena pengaruh angin, gelombang, dan arus ${ }^{(9)}$. Angin yang berhembus di Perairan Cilacap cukup kencang dengan kecepatan angin terbesar terjadi pada bulan Agustus-September dengan kecepatan maksimum mencapai $20-25 \mathrm{~m} / \mathrm{s}$ berdasarkan data dari Pelabuhan Cilacap ${ }^{(10)}$. Angin yang berhembus di atas Perairan Cilacap merupakan faktor 
pembangkit gelombang laut. Gelombang laut di pantai Teluk Penyu, Cilacap memiliki tinggi maksimum 2.4 meter ${ }^{(11)}$. Angin yang bertiup di atas permukaan laut selain menyebabkan terjadinya gelombang laut juga menimbulkan arus laut(12). Perairan Cilacap mempunyai aliran arus yang kuat ${ }^{(13)}$. Selain angin, aliran arus laut yang kuat juga disebabkan oleh variasi tinggi muka air yang dipengaruhi kondisi pasang surut dan topografi perairan karena perairan Cilacap yang merupakan bagian dari perairan Samudera Hindia memiliki dasar perairan yang dalam dan curam ${ }^{(14)}$.

Seperti diketahui bahwa tumpahan minyak sangat berdampak negatif terhadap lingkungan dan kehidupan manusia di sekitarnya terutama pada kawasan yang sangat sensitif terhadap tumpahan minyak seperti laguna Segara Anakan dan kawasan wisata Teluk Penyu(15). Sebagai contoh kasus kecelakaan kapal tanker King Fisher pada April tahun 2000 yang mencemari perairan Teluk Cilacap, Jawa Tengah. Sepanjang 10 kilometer mulai dari Area 70 di wilayah Kelurahan Cilacap, Pantai Teluk Penyu - Pantai Tegal Kamulyan - Lengkong(2). Oleh karena itu kejadian tumpahan minyak di laut harus sesegera mungkin ditanggulangi sebelum menyebar luas dan tidak terkendali dengan tujuan penyelamatan lingkungan dan perikehidupan manusia. Pemerintah telah mengeluarkan Peraturan Presiden No. 109 tahun 2006 tentang Penanggulangan Keadaan Darurat Tumpahan Minyak di Laut yang mengamanatkan perlunya penanggulangan tumpahan minyak yang cepat, tepat dan terukur ${ }^{(16)}$. Salah satu upaya yang dapat dilakukan untuk melakukan penanggulangan tumpahan minyak yang cepat dan tepat adalah pemodelan persebaran dan konsentrasi tumpahan minyak sehingga nantinya resiko akibat pencemaran minyak tersebut dapat diminimalisasi. Dengan mengetahui hal tersebut akan dapat disusun upaya penanggulangan (contingency planning) yang paling efektif dan efisien, karena telah ada urutan prioritas penanganan pada daerah yang berpotensi tercemar. Prioritas ini akan sangat membantu dalam pengalokasian sumberdaya sesuai tingkat resiko yang mungkin terjadi. Untuk penyusunan prioritas lokasi penanganan didasarkan pada pola dan waktu persebaran minyak serta konsentrasi (ketebalan slick) yang mungkin terjadi di setiap lokasi yang terkena tumpahan minyak. Proses pergerakan dan penyebaran tumpahan minyak di laut disimulasikan dengan model matematik lintasan tumpahan minyak dengan memperhatikan kondisi angin dan arus laut (dalam kajian ini menggunakan software MIKE 21 dari DHI). MIKE 21 saat ini merupakan software pemodelan tumpahan minyak yang handal dan pemodelan tumpahan minyak dengan MIKE 21 telah banyak dilakukan di seluruh dunia. Pemodelan tumpahan minyak di Cilacap pernah dilakukan oleh Widhayanti, 2015(17) dengan sumber tumpahan minyak pada lokasi CIB (Crude Berth Island) dan fokus pada pengaruh pasang surut terhadap sebaran tumpahan minyak. Hasil kajian tumpahan minyak di Cilacap juga dilakukan oleh Saepudin dkk (2008) dengan menggunakan interpretasi citra Modis Surface Reflectane(18). Sedangkan pada kajian ini dilakukan dengan menggunakan software MIKE 21 dengan sumber tumpahan minyak berasal dari pelabuhan bongkar muat area 70 dan pada lokasi SPM (single point mooring) (lihat Gambar 2) dengan skenario pada musim barat (8-14 Januari 2012) dan musim timur (10-16 September 2012). Hasil pemodelan ini diharapkan dapat memperkaya, melengkapi dan menajamkan hasil kajian terdahulu. Hasil pemodelan ini merupakan dasar utama untuk menyusun rencana aksi dalam sistem peringatan dini dan upaya penanggulangan (contingency planning) yang paling efektif dan efisien $(17,20,21)$.

\subsection{Tujuan Penelitian}

Tujuan penelitian ini adalah untuk mengetahui persebaran dan ketebalan slick tumpahan minyak di perairan Cilacap dan sepanjang kawasan pantai Cilacap berdasarkan skenario-skenario yang disusun. Sedangkan sasaran dari penelitian ini adalah terkumpulnya data geobiofisik kawasan pesisir Cilacap dan tumpahan minyak yang terjadi di pesisir Cilacap, diketahuinya kondisi hidrodinamika perairan Cilacap dan diperolehnya model tumpahan minyak di kawasan pesisir Cilacap.

\section{BAHAN DAN METODE}

\subsection{Model Tumpahan Minyak MIKE 21}

Minyak yang tumpah ke atas permukaan air cenderung untuk menyebar ke arah luar sehingga membentuk suatu lapisan yang tipis. 
Kecenderungan untuk menyebar ini merupakan pengaruh dua gaya fisis yaitu gaya gravitasi dan tegangan permukaan. Dalam gerakannya yang menyebar itu tumpahan minyak diperlambat oleh gaya inersia dan gaya viskos. Oleh karena itu penyebaran tumpahan minyak dihitung dalam tiga regime yang berubah dalam waktu yaitu regime gravitasi-inersia, regime gravitasi-viskos, dan regime tegangan permukaan (22).

Saat ini telah banyak dikembangkan modelmodel untuk mengetahui persebaran tumpahan minyak salah satu yang terbaru dan dianggap komprehensif adalah model tumpahan minyak dari DHI (Danish Hydraulic Institute) yang diwujudkan dalam modul oil spill di perangkat lunak MIKE 21. Program yang digunakan adalah MIKE 21 dari DHI modul Particle/Spill Analysis. Pemodelan tumpahan minyak dengan MIKE 21 telah banyak dilakukan dan sangat membantu dalam usaha untuk meminimalisir dampak negatif seperti yang di lakukan di Goa, Pantai Barat India ketika terjadi tumpahan minyak pada 23 Maret 2005 akibat tabrakan dua kapal(23). Selain itu digunakan untuk pemodelan tumpahan minyak di pelabuhan Lach Huyen di timur laut Vietnam pada tahun 2011(24) serta tumpahan minyak di Laut Adriatic Utara(25).

Model tumpahan minyak MIKE 21- DHI ini merupakan alat untuk memprediksi fate tumpahan minyak di laut, baik transpornya maupun perubahan komposisi kimianya. Model ini merupakan Model Langrangian yang dipacu terpisah dari model hidrodinamik. Hasil pemodelan hidrodinamika dipakai untuk pemodelan tumpahan minyak. Dalam model pelapukan tumpahan minyak $\mathrm{DHI}$ ini, digambarkan bahwa minyak terdiri hanya dua fraksi yaitu fraksi yang ringan dan volatil serta fraksi yang lebih berat. Fraksi ringan dan volatil didifinisikan sebagai massa hidrokarbon dengan berat molekul kurang dari $160 \mathrm{~g} / \mathrm{mol}$ dan titik didih kurang dari $300^{\circ} \mathrm{C}$. Fraksi yang lebih berat didefinisikan sebagai hidrokarbon dengan berat molekul di atas $160 \mathrm{~g} / \mathrm{mol}$ dan titik didih antara 250-300 ${ }^{\circ} \mathrm{C}$ atau lebih, mencakup komponen wax dan aspal(26,27).

\subsection{Lokasi Kegiatan}

Secara spasial kajian ini berada di sekitar muara K. Donan, dengan batas utara sekitar area
60 Pertamina UP IV, Cilacap, bagian selatan P. Nusakambangan, bagian timur sekitar PLTU Cilacap dan sebelah barat sekitar Sungai Donan (lihat Gambar 1).

\subsection{Data Masukan}

Untuk pelaksanaan kegiatan ini dibutuhkan banyak data masukan untuk pemodelan serta dibutuhkan peralatan baik berupa perangkat keras maupun lunak yang cukup banyak. Data-data yang dibutuhkan adalah batimetri dari GITEWS, 2010(27), pasang surut (dari Tide Model Driver/TMD)(28), debit sungai di boundary dari Balai Besar Wilayah Sungai Serayu dan Opak, $2010{ }^{(29)}$, asumsi waktu terjadinya, posisi sumber tumpahan minyak, suhu dan salinitas air laut, arah-kecepatan angin-suhu udara dari BMKG, 2012(11), asumsi volume minyak yang tumpah, proses tumpah (sesaat atau terus menerus), karakteristik minyak. Pemodelan ini dilakukan untuk skenario 8-14 Januari 2012 (mewakili musim barat) dan 1016 September 2012 (mewakili musim timur). Detail jenis data inputan sebagaimana terlihat dalam Tabel 1.

\subsection{Tahapan Pelaksanaan Penelitian}

Secara umum tahapan pelaksanaan penelitian ini dimulai dari pengumpulan data sekunder dan studi literature, penyusunan skenario pemodelan, penyiapan data masukan model, setup dan pacu model, analisis hasil pemodelan dan penyusunan rekomendasi untuk meminimalisir resiko tumpahan minyak.

\subsection{Skenario Tumpahan Minyak}

Untuk memodelkan tumpahan minyak yang sering terjadi di perairan Cilacap disusun 4 (empat) skenario. Delapan skenario tersebut terlihat pada tabel 1 di bawah ini. Pemilihan lokasi tumpahan minyak di Dermaga 1 Pelabuhan Area 70 dan SPM Pertamina Cilacap didasarkan pada informasi dan pertimbangan bahwa tumpahan minyak paling sering terjadi pada saat bongkar muat. Pada dua lokasi tersebutlah proses bongkar muat dilakukan. Untuk dermaga sebenarnya di Pelabuhan Area 70 terdapat 3 dermaga yang lokasinya berdekatan, sehingga tumpahan pada dermaga lain dianggap relatif sama. Pelabuhan Area 70 berada di sisi timur muara S. Donan sedangkan SPM Pertamina Cilacap berada di sebelah timur P. Nusakambangan (Gambar 2). 

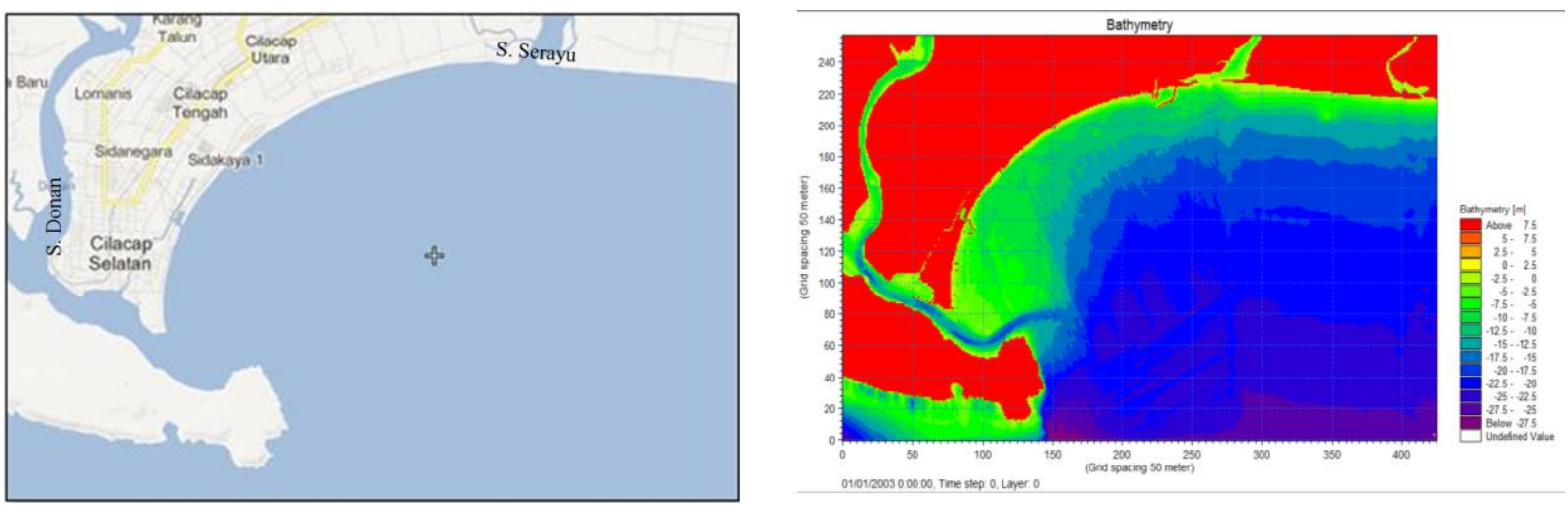

Gambar 1. Batasan daerah penelitian dan domain pemodelan

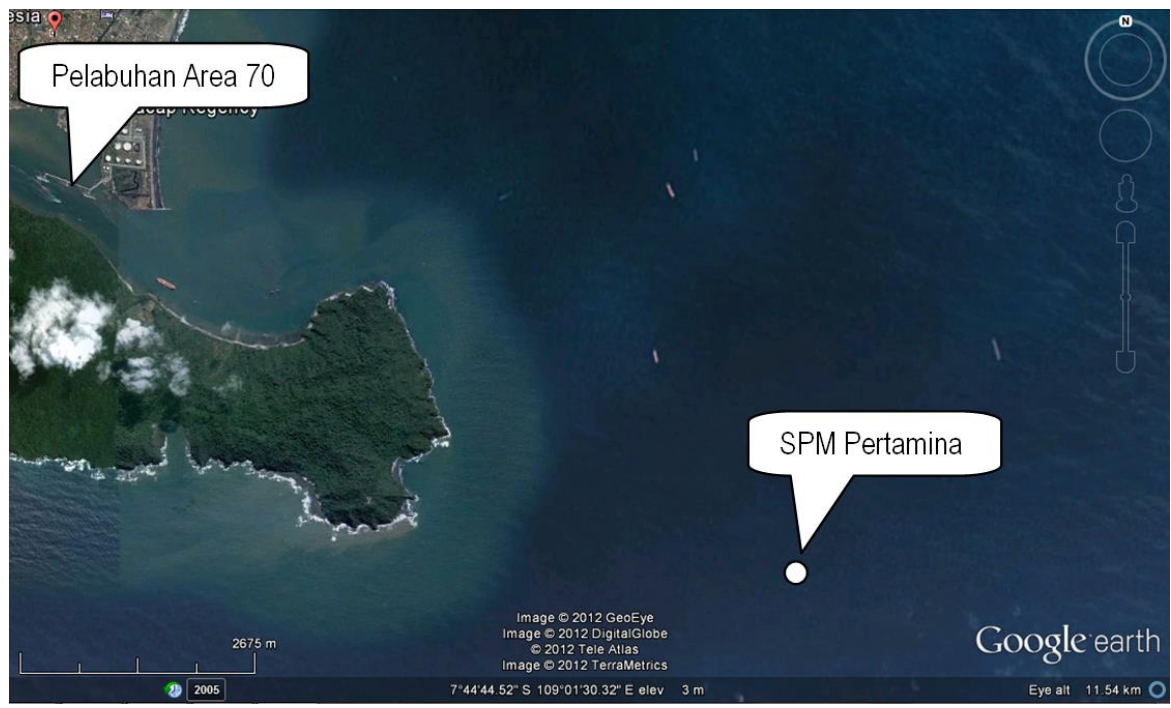

Gambar 2. Posisi lokasi tumpahan minyak

Tabel 1. Skenario tumpahan minyak di Perairan Cilacap

\begin{tabular}{|c|c|c|c|c|}
\hline \multirow{2}{*}{ PARAMETER INPUT } & \multicolumn{4}{|c|}{ SKENARIO } \\
\hline & $\mathbf{I}$ & II & III & IV \\
\hline Vol. Disharge(barrel) & 1000 & 1000 & 1000 & 1000 \\
\hline Lokasi & $\begin{array}{l}\text { Dermaga } 1 \\
\text { Pelabuhan Area } 70\end{array}$ & $\begin{array}{l}\text { SPM Pertamina } \\
\text { Cilacap }\end{array}$ & $\begin{array}{l}\text { Dermaga } 1 \\
\text { Pelabuhan Area } 70\end{array}$ & $\begin{array}{l}\text { SPM Pertamina } \\
\text { Cilacap }\end{array}$ \\
\hline \multirow{2}{*}{ Koordinat } & $109^{\circ} 00^{\prime} 43,5^{\prime \prime}$ BT & 10905'20,36" BT & $109^{\circ} 00^{\prime} 43,5^{\prime \prime}$ BT & $109^{\circ} 05^{\prime} 20,36^{\prime \prime} \mathrm{BT}$ \\
\hline & $07^{\circ} 45^{\prime} 01,00^{\prime \prime} \mathrm{LS}$ & $07^{\circ} 49^{\prime} 16,18 " \mathrm{LS}$ & $07^{\circ} 45^{\prime} 01,00^{\prime \prime}$ LS & $07^{\circ} 49^{\prime} 16,18^{\prime \prime} \mathrm{LS}$ \\
\hline Waktu & \multicolumn{2}{|c|}{ Tanggal 8-14 Januari 2012} & \multicolumn{2}{|c|}{ Tanggal 10 - 16 September 2012} \\
\hline DurasiDischarge(jam) & \multicolumn{4}{|l|}{5} \\
\hline Bathymetri & \multicolumn{4}{|c|}{ Hasil Pemetikan Data GITEWS ${ }^{(27)}$} \\
\hline Grid Domain & \multicolumn{4}{|c|}{ Interval 50 m (425 grid x 257 grid $)$} \\
\hline Suhu Air $\left({ }^{\circ} \mathrm{C}\right)$ & \multicolumn{4}{|l|}{25} \\
\hline Salinitas (\%o) & \multicolumn{4}{|l|}{35} \\
\hline
\end{tabular}




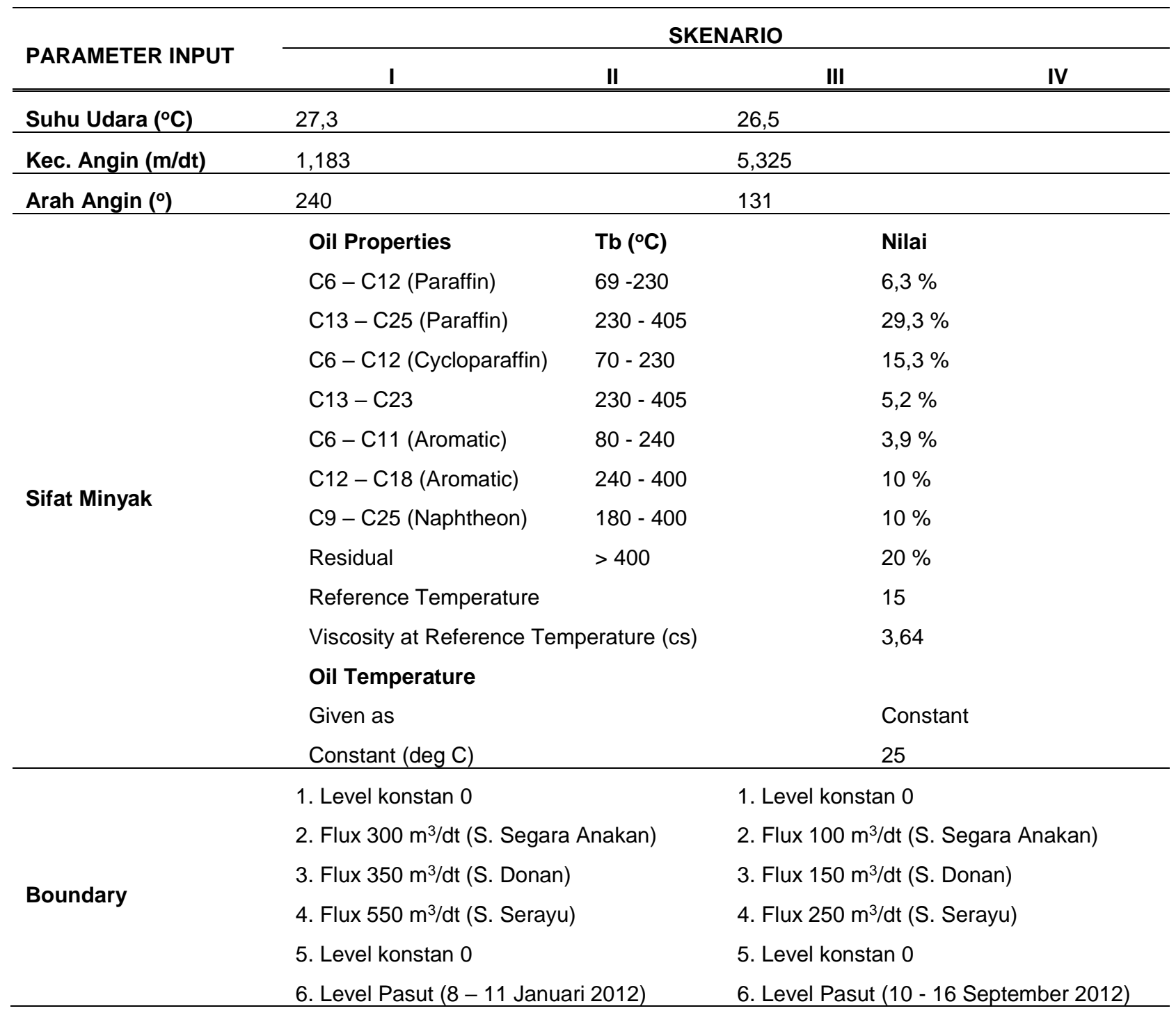

\section{HASIL DAN PEMBAHASAN}

Berdasarkan hasil pacu model sesuai dengan skenario tersebut di atas, arah persebaran tumpahan minyak dan ketebalan slick minyak berbeda-beda. Uraian hasil pemodelan dan pembahasan setiap skenario diuraikan sebagai berikut.

\subsection{Pemodelan Skenario 1}

Hasil dari skenario pada awal tumpahan, minyak hanya tersebar di sekitar muara S. Donan, kemudian mulai menyebar semakin jauh ke arah hulu sampai muara S. Yasa dan ke hilir sampai di pantai utara P. Nusakambangan sebelah timur. Hal ini kemungkinan terjadi ketika kondisi pasang, sesuai dengan hasil penelitian Widhayanti dkk (2015) yang menyatakan bahwa pada kondisi pasang minyak tersebar ke arah barat laut (17).
Setelah sekitar 10 jam slick minyak semakin banyak tersebar di perairan laut Nusakambangan bagian timur. Ketebalan slick minyak rata-rata berkisar 0,06 - 0,12 mm kecuali di sekitar pelabuhan Pertamina Area 70 yang berkisar antara 0,3-1,32 mm. Pada hari kedua (setelah 24 jam) slick minyak mulai banyak yang menyebar ke tengah perairan laut tidak hanya di pinggiran pantai. Hal ini kemungkinan terjadi ketika kondisi surut, sesuai dengan hasil penelitian Widhayanti dkk (2015) yang menyatakan bahwa pada kondisi surut minyak tersebar ke arah tenggara (17)Setelah 56 jam dari terjadinya tumpahan slick minyak mulai banyak yang menghilang dan hanya tersisa di lokasi-lokasi tertentu yaitu di pantai sekitar pelabuhan Pertamina area 70 (ketebalan slick 0,6 - 2,1 $\mathrm{mm}$ ), pantai utara dan timur $P$. Nusakambangan bagian timur dan di sisi timur $\mathrm{S}$. Donan (ketebalan slick minyak 0,06-0,12 mm). Ketebalan maksimum minyak di perairan Cilacap 
hasil pemodelan selama waktu simulasi hasil berikut ini. pemodelan skenario 1 terlihat pada Gambar 3

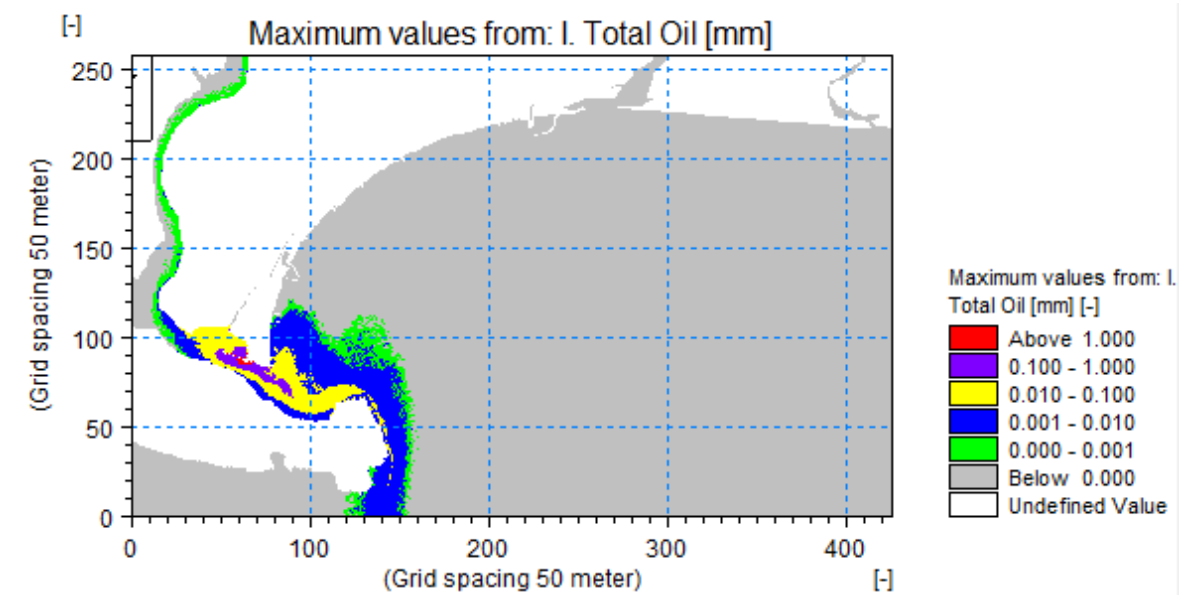

Gambar 3. Sebaran nilai maksimum ketebalan slick minyak pada pemodelan skenario 1 selama waktu simulasi

\subsection{Pemodelan Skenario 2}

Dari hasil pacu model skenario 2 ini, tidak banyak yang dapat dideskripsikan karena tumpahan minyak sebagian besar tersebar ke arah selatan dan keluar dari domain model yang telah ditetapkan. Hanya pada 1-2 jam pertama tumpahan saja slick minyak tersebar sedikit di utara titik SPM Pertamina Cilacap (dengan ketebalan sangat tipis $<0,001 \mathrm{~mm}$ ).

\subsection{Pemodelan Skenario 3}

Pada awal tumpahan minyak (1 - 7 jam setelah minyak tumpah), tumpahan minyak tersebar di sekitar pelabuhan dan cenderung bergerak ke arah hulu S. Donan dan sebagian besar terakumulasi di muara S. Yasa. Hal ini kemungkinan terjadi ketika kondisi pasang, sesuai dengan hasil penelitian Widhayanti dkk (2015) yang menyatakan bahwa pada kondisi pasang minyak tersebar ke arah barat laut ${ }^{(17)}$.

Pada awal tumpahan minyak (1 - 7 jam setelah minyak tumpah), minyak tersebar di sekitar pelabuhan dan cenderung bergerak ke arah hulu S. Donan dan sebagian besar terakumulasi di muara S. Yasa (ketebalan sekitar 0,5846 mm). Kemudian slick minyak mulai bergerak semakin jauh ke arah hulu S. Donan (ketebalan $<0,5846 \mathrm{~mm}$ ), minyak yang di muara $S$. Yasa sudah mulai menghilang yang tersisa hanya yang ada di sekitar pelabuhan (dekat dengan sumber tumpahan) dengan ketebalan slick antara 1,169-15,2 mm. Setelah jam ke-20 sebaran tumpahan minyak semakin tersebar ke arah hulu S. Donan dan relatif terakumulasi di sisi barat S. Donan (dengan ketebalan relatif tipis $<0,5846 \mathrm{~mm}$ ). Memasuki hari ke-2 (jam ke-40) tumpahan minyak semakin bergerak ke hulu dan sudah mulai banyak yang keluar domain model. Sedangkan yang di sekitar pelabuhan minyak masih tersisa dengan ketebalan yang secara umum semakin menipis. Kecuali pada lokasi yang agak terlindung (disisi dalam bangunan dermaga ada bebarapa lokasi yang ketebalan slick minyak sangat tebal $>2,6$ $\mathrm{mm})$. Ketebalan maksimum minyak di perairan Cilacap hasil pemodelan selama waktu simulasi hasil pemodelan skenario 3 terlihat pada Gambar 4 berikut ini. 
Gambar 4. Sebaran nilai maksimum ketebalan slick minyak pada pemodelan

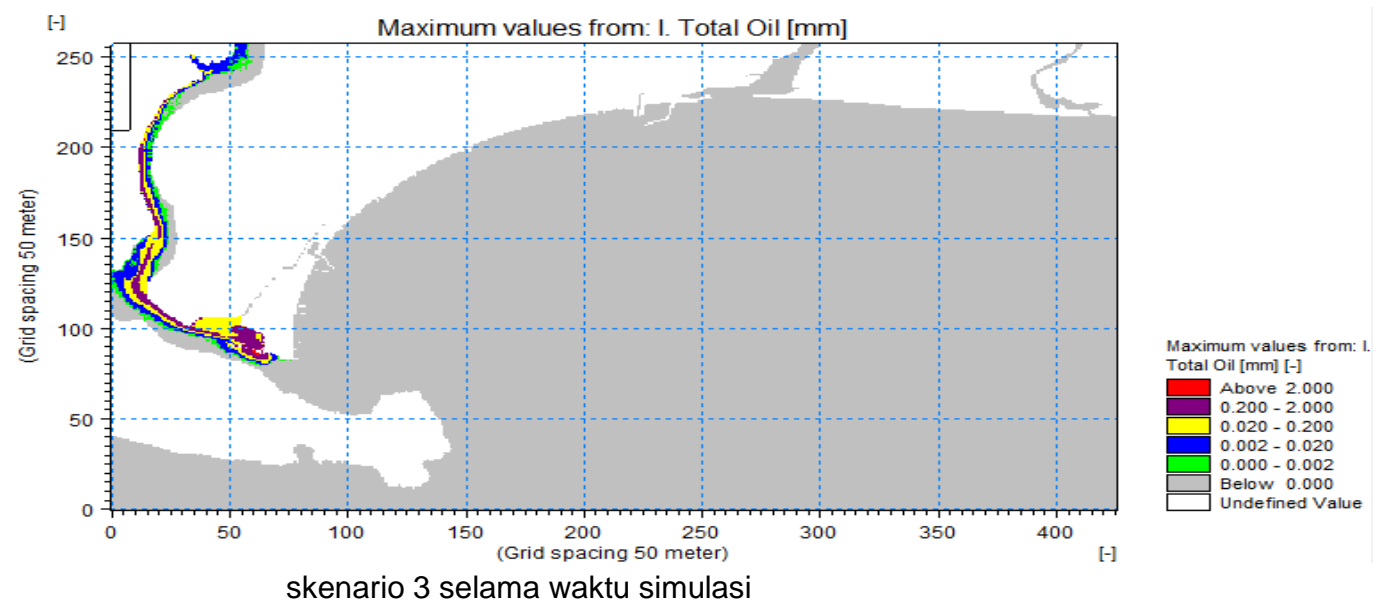

\subsection{Pemodelan Skenario 4}

Pada awal tumpahan minyak (5 jam pertama), slick minyak mulai menyebar ke arah utara (menuju ke arah pantai) membentuk plume dengan ketebalan slick antara 0,052 $0,1561 \mathrm{~mm}$. Setelah $12 \mathrm{jam}$, tumpahan minyak telah mencapai garis pantai terutama di sebelah barat muara S. Serayu, sedangkan plume bagian selatan mulai bergerak ke arah barat mendekati P. Nusakambangan. Hal ini kemungkinan terjadi ketika kondisi pasang, sesuai dengan hasil penelitian Widhayanti dkk (2015) yang menyatakan bahwa pada kondisi pasang minyak tersebar ke arah barat laut ${ }^{(17)}$. Setelah itu minyak mulai bergerak tersebar ke arah barat sepanjang garis pantai dan mencapai muara S. Donan pada jam ke-22. Demikian juga plume bagian selatan sudah mencapai dan tersebar di sepanjang pantai timur P. Nusakambangan. Setelah itu sampai jam ke-48 slick minyak yang ada di timur $P$. Nusakambangan bergerak ke arah utara menuju pantai Teluk Penyu dan sebagian ada yang masuk agak ke hulu sampai muara S. Yasa (dengan ketebalan 0,052-0,1041 mm). Slick minyak di P. Nusakambangan tinggal tersebar setempat-setempat di pantai selatan $P$. Nusakambangan bagian timur dengan ketebalan rata-rata $0,05203-0,0015486764$ $\mathrm{mm}$. Setelah itu slick minyak di alur S. Donan semakin bergerak ke arah hulu dan pergerakan dan perubahan konsentrasi minyak terjadi di Teluk Penyu bagian barat, ada juga slick minyak yang terjebak di sisi dalam dermaga pelabuhan pertamina yang ketebalan mencapai $1,457 \mathrm{~mm}$. Pada akhir simulasi (hari ke 6), slick minyak tersebar di sepanjang Teluk Penyu dengan ketebalan bervariasi antara 0,05203 - 1,041 mm, di sekitar pelabuhan Pertamina Area 70, di sisi barat agak ke hulu S. Donan serta di sepanjang pantai $P$. Nusakambangan bagian selatan dan timur. Ketebalan maksimum minyak di perairan Cilacap hasil pemodelan selama waktu simulasi hasil pemodelan skenario 4 terlihat pada Gambar 5. 


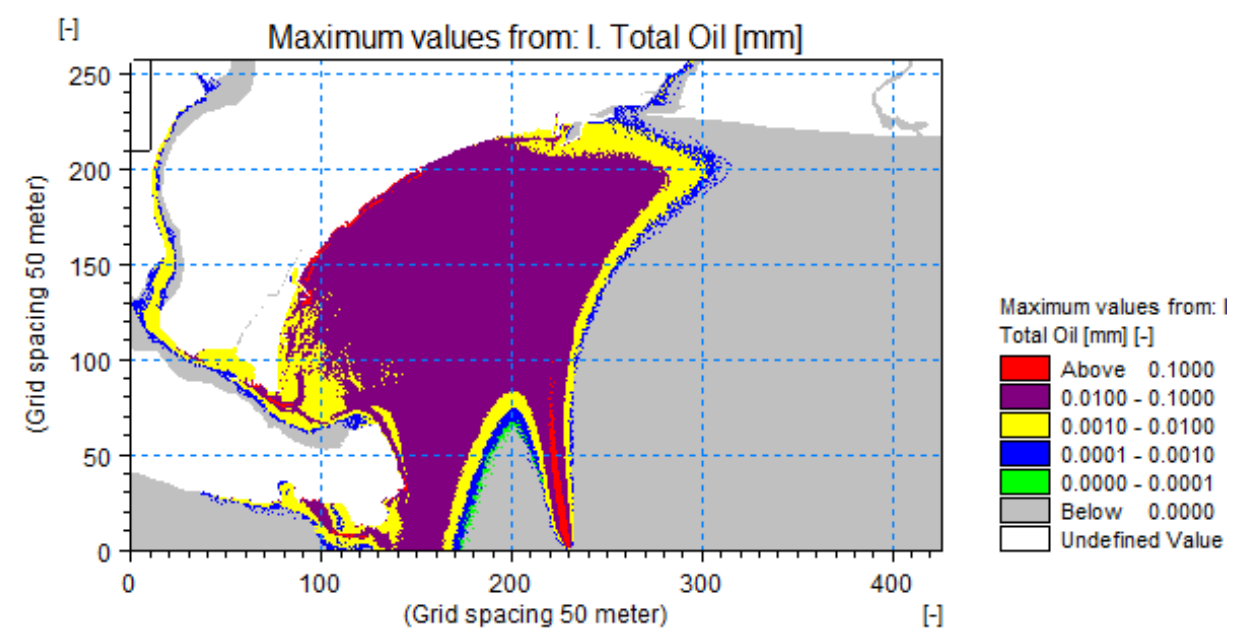

Gambar 5. Sebaran Nilai Maksimum Ketebalan Slick Minyak pada pemodelan

Skenario 4 Selama Waktu Simulasi

\subsection{Validasi}

\subsubsection{Validasi Hasil Pemodelan Pasang Surut 8-14 Januari 2012}

Validasi pasang surut hasil pemodelan hidrodinamika perairan Cilacap pada tanggal 8 14 Januari 2012 didasarkan pada hasil pengukuran yang dilakukan oleh Intergovernmental Oceanographic Commission $(I O C, 2012)^{(30)}$. Stasiun pengukuran dari IOC di Cilacap terletak di muara Sungai Donan dekat dengan dermaga Pertamina di Area 70, pada koordinat 7,75 LS dan 109 BT. Berdasarkan data pengukuran tersebut, terdapat kemiripan antara hasil pemodelan dengan data pengukuran yang dilakukan oleh IOC. Dari hasil analisis kedua data tersebut di atas diperoleh nilai Root Mean Square Deviation (RMSD) sebesar 0.350571514 dan Normalized Root Mean Square Deviation (NRMSD) sebesar 0.636789103. Dari nilai RMSD dan NRMSD tersebut di atas dapat disimpulkan bahwa tidak ada beda nyata antara hasil pemodelan dengan hasil pengukuran. Grafik perbandingan pasang surut antara hasil pemodelan dengan hasil pengukuran yang dilakukan oleh IOC terlihat seperti pada gambar di bawah ini.

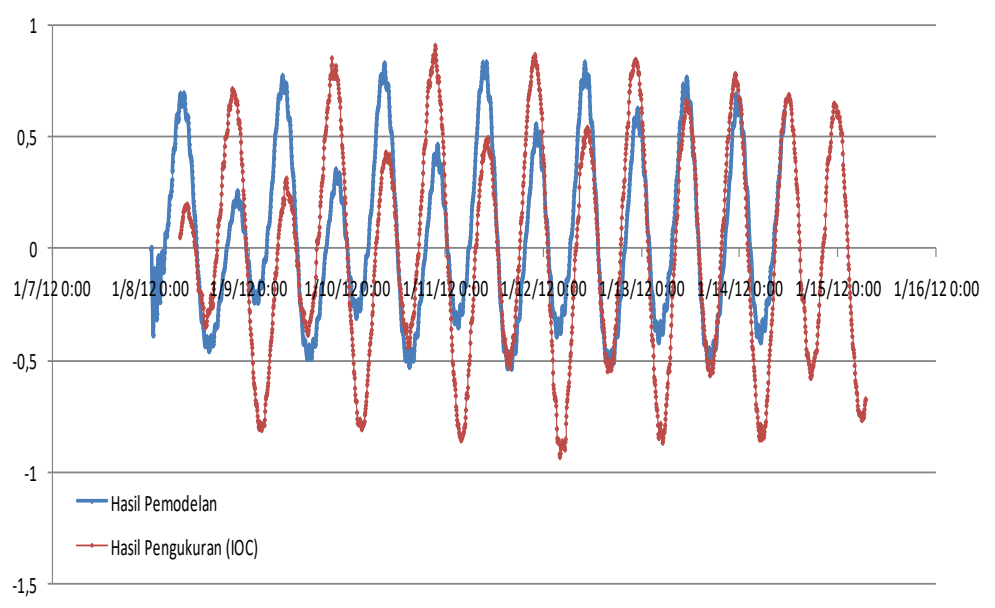

Gambar 6. Perbandingan Data Pasang Surut Hasil Pemodelan \& Pengukuran IOC periode 8-14 Januari 2012 


\subsubsection{Validasi Hasil Pemodelan Pasang Surut 10-16 September 2012}

Validasi pasang surut hasil pemodelan hidrodinamika perairan Cilacap pada tanggal 10 - 16 September 2012 didasarkan pada hasil pengukuran yang dilakukan oleh Intergovernmental Oceanographic Commission/ IOC pada tahun $2012^{(27)}$. Stasiun pengukuran dari IOC di Cilacap terletak di muara Sungai Donan dekat dengan dermaga Pertamina di Area 70, pada koordinat 7,75 LS dan 109 BT. Berdasarkan data pengukuran tersebut, terdapat kemiripan antara hasil pemodelan dengan data pengukuran yang dilakukan oleh IOC. Dari hasil analisis kedua data tersebut di atas diperoleh nilai Root Mean Square Deviation (RMSD) sebesar 0.389659555 dan NormalizedRoot Mean Square Deviation (NRMSD) sebesar 0.384501723. Dari nilai RMSD dan NRMSD tersebut di atas dapat disimpulkan bahwa tidak ada beda nyata antara hasil pemodelan dengan hasil pengukuran. Grafik perbandingan pasang surut antara hasil pemodelan dengan hasil pengukuran yang dilakukan oleh IOC terlihat seperti pada gambar di bawah ini.

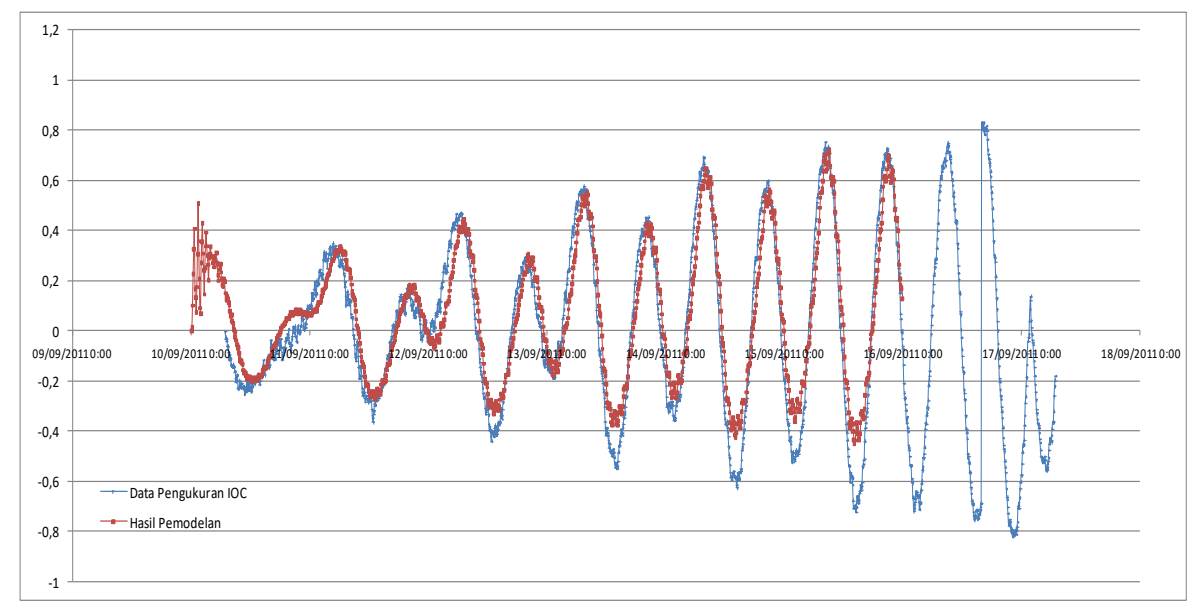

Gambar 7. Perbandingan Data Pasang Surut Hasil Pemodelan \& Pengukuran IOC periode 10-16 September 2012

\section{KESIMPULAN}

Hasil pemodelan skenario 1 tumpahan minyak menyebar ke hulu S. Donan, pantai Teluk Penyu bagian selatan dan sebelah utara dan timur P. Nusakambangan dengan ketebalan slick minyak antara 0,0001-2,1 mm. Semakin jauh dari sumber tumpahan minyak, ketebalan slick minyak semakin menipis. Hasil pemodelan skenario 2 tumpahan minyak sebagian besar tersebar ke arah selatan dan keluar dari domain model.Hasil pemodelan skenario 3, tumpahan minyak hanya menyebar ke arah utara (hulu $\mathrm{S}$. Donan) karena arus dan angin dominan dari arah tenggara. Ketabalan slick minyak bervariasi dari $0,001-2,7 \mathrm{~mm}$. Ketebalan minyak terbesar berada di dekat sumber tumpahan dan di tengah alur aliran sungai.Hasil pemodelan skenario 4, tumpahan minyak menyebar merata di seluruh perairan Cilacap dan S. Donan. Ketebalan slick minyak bervariasi dari $0,001-1,0 \mathrm{~mm}$. Ketebalan minyak terbesar berada di dekat sumber tumpahan dan di sepanjang pantai Teluk Penyu. Persebaran tumpahan minyak sangat dipengaruhi oleh lokasi sumber, kondisi hidrooseanografi (arus) dan meteorologi (angin). Ketebalan slick tumpahan minyak sangat dipengaruhi oleh debit tumpahan minyak.

\section{PERSANTUNAN}

Terima kasih kepada seluruh manajemen BPDP dan seluruh anggota tim "Kajian Pengelolaan Kawasan Pesisir Untuk Mitigasi dan Adaptasi Terhadap Perubahan Iklim/ Bencana Pantai" Tahun 2012-2013 di Balai Pengkajian Dinamika Pantai-BPPT. 


\section{DAFTAR PUSTAKA}

1. Mauludiyah.(2012). Estimasi Biaya Kerugian Akibat Tumpahan Minyak di Perairan Cilacap, Thesis Program Magister, Bidang Keahlian Teknik Manajemen Pantai Program Studi Teknologi Kelautan, Fakultas Teknologi Kelautan di Institut Teknologi Sepuluh Nopember, Surabaya (tidak dipublikasikan).

2. Pristiyanto, D. (2000). Tanker MT King Fisher Kandas, Teluk Cilacap Tercemar Minyak dalam http://kompas.com/kompascetak/0004/05/IPTEK/tang10.htm Rabu, 5 April 2000, diakses tanggal 10 Juli 2012 jam 09.10 WIB.

3. Pertamina UP IV.(2004).Pemeriksaan Dampak Kebocoran Kapal MT Lucky Lady Di Perairan Teluk Penyu Cilacap, HUPMAS/ UMUM UP IV No. B4 II/ E14620/ 2004-SO, Cilacap

4. Anonim.(2008). Perairan Cilacap Tercemar MFO dalam http://www.suaramerdeka.com/v1/index.ph p/read/cetak/2008/04/05/7769/PerairanCilacap-Tercemar-MFO-, 5 April 2008, diakses tanggal 15 Oktober 2012 jam 10.30 WIB.

5. Widiyanto, E. (2010). Rekanan Pertamina Tumpahkan Minyak, Nelayan Cilacap Tuntut Rp 10 M, dalam http://www.republika.co.id/berita/breakingnews/nusantara/10/10/06/ 138373rekanan-pertamina-tumpahkan-minyaknelayan-cilacap-tuntut-rp-10-m Rabu, 06 Oktober 2010, 04:04 WIB, diakses tanggal 15 Oktober 2012 jam 10.15 WIB

6. Anonim.(2011). Minyak Cemari Pantai Cilacap, Nelayan Minta Ganti Rugi, dalam http://www.pikiran-

rakyat.com/node/151697Selasa, 12/07/2011 - 19:57, diakses tanggal 15 Oktober 2012 jam 10.30

7. Wagino.(2011). Minyak Tumpah Di Perairan Cilacap Akibat Pipa Bocor, dalam http://cilacapmedia.com/index.php/seputarcilacap/1650-minyak-tumpah-di-perairancilacap-akibat-pipa-bocor.html Senin, 12 September 2011 17:35, diakses tanggal 15 Oktober 2012 jam 11.00 WIB.

8. Sumarwoto. (2015). Minyak Tumpah di Cilacap Jenis MFO 180 dalam http://www.antaranews.com/berita/499229/ minyak-tumpah-di-cilacap-jenis-mfo-180 diakses 09 Nopember 2017 jam 09.00 WIB.

9. Fingas, M. (2013). The Basics of Oil Spill Cleanup. 3rd ed., CRC Press LLC, Florida: $247 \mathrm{p}$.

10. Triatmodjo B. (1999). Teknik Pantai. Penerbit BETA OFFSET, Edisi Pertama, Yogyakarta: $397 p$

11. BMKG.(2012). Informasi Meteorologi Maritim, dalam http://maritim.bmkg.go.id/index.php/main/st asiun maritim/8.

12. Hadi, S. dan Radjawane, I.M. (2009). Arus Laut. Institut Teknologi Bandung, Bandung. [ITOPF] International Tanker Owners of Pollution Federation Limited. 2002. Fate of Marine Oil Spill, Technical Information. http://www.itopf.com/ marinespills/fate/weatheringprocess/docum ents/tip2.pdf (04 April 2014).

13. Sudaryanto, Agus. (2001). Struktur Komunitas Makrozoobenthos Dan Kondisi Fisiko Kimiawi Sedimen di Perairan Donan, Cilacap - Jawa Tengah. Jurnal Teknologi Lingkungan. Jurnal Teknologi Lingkungan, Vol.2, No. 2, Mei 2001 : p 119-123

14. Saputra, Wijaya, S., Solichin, A. dan Rizkiyana, W. (2013). Keragaman Jenis dan Beberapa Aspek Biologi Udang Metapenaeus di Perairan Cilacap, Jawa Tengah. Journal of Management of Aquatic Resources. Fakultas Perikanan dan IImu Kelautan Universitas Diponegoro, Semarang.Vol 2 No 3 Tahun 2013 : p 3746.

15. Wibowo M., Prijambodo T., Triwibowo M. (2012). The Mapping Environmental Sensitivity Indek to The Oil Spill In Coastal Areas of Cilacap, Proceeding of "The Second International Conference on Port, Coastal, and Offshore Engineering (2nd ICPCO)", Bandung, 12-13 November 2012: $9 \mathrm{p}$.

16. Anonim.(2006). Peraturan Presiden No. 109 tahun 2006 tentang Penanggulangan Keadaan Darurat Tumpahan Minyak di Laut.

17. Widhayanti A., Ismanto A., Yulianto B. (2015). Sebaran Tumpahan Minyak degan Pendekatan Pemodelan Hidrodinamika dan Spill Analysis di Perairan Cilacap, Jawa 
Tengah, Jurnal Oseanografi Vol 4 No4. Tahun 2015: p. 641-650.

18. Saepudin A., Rokhmatuloh, Handayani T. (2008). Sebaran Tumpahan Minyak di Perairan Cilacap Tahun 2008. Departemen Geografi, F MIPA Universitas Indonesia

19. Hadi, S., dan Latief, H. (2008). Pemodelan Tumpahan Minyak, Peringatan Dini Penanggulangan, Dan Analisis Tingkat Kerusakan Lingkungan Di Indonesia Pengembangan Model Matematik Dan Penerapan Sistem Informasi Geografis Untuk Menunjang Rencana Strategis Penanggulangan Tumpahan Minyak Di Selat Malaka, Selat Lombok Dan Selat Makasar, Makalah Lepas di Lab. Oseanografi Pantai, FIKTM ITB : 54p.

20. Wibowo, M. (2013).Pengembangan Konsep Sistem Informasi Peringatan Dini Tumpahan Minyak di Pesisir Cilacap, Jurnal IPTEK-KOM Balai Pengkajian dan Pengembangan Komunikasi dan Informatika, Yogyakarta Vol. 15. 1 Juni 2013: p 17-26.

21. DHI.(2011). DHI Oil Spill Model-Oil Spill Template-Scientific Documentation, MIKE by DHI: $108 p$

22. Vethamony, P, dkk.(2007).Trajectory of on Oil Spill off Goa, Eastern Arabian Sea: Field Observatins and Simulations. Science Direct-Environmental Pollution 148 (2007): p438-444.

23. Quang, D., Don, NC., Ching, Y. (2013). Trajectory Modeling of Marine Oil Spills : Case Study of Lach Huyen Port. Vietnam, Lowland Technology International, International Association of Lowland
Technology. Vietnam. Vol 15 No 2. December 2013: p. 41-55.

24. Loncar, G., Leader, N., dan Paladin, M. (2012). Numerical Modelling of an Oil Spill in Northern Adriatic. Polish Academy of Sciences. Institute of Oceanology. Zagrep, Croatia.Oceanologia, 54 (2), 2012: p. 143173.

25. DHI.(2011). MIKE-21 \& MIKE 3 PA/SA, User Guide Particle Analysis dan Spill Analysis, MIKE by DHI: $48 \mathrm{p}$.

26. DHI.(2011). MIKE-21/3 Oil Spill, User Guide Oil Spill Model. MIKE by DHI: $50 \mathrm{p}$.

27. GITEWS.(2010).Dokumentasi Teknis : Peta Bahaya Tsunami untuk Kabupaten Cilacap (Peta Bahaya Tsunami Multi-skenario untuk Kabupaten Cilacap, Skala 1:100.000; Peta Bahaya Tsunami Multi-skenario untuk Kota Cilacap, Skala 1:30.000), GITEWS (German Indonesia Tsunami Early Warning System) dan Pemerintah Kabupaten Cilacap: $27 \mathrm{p}$

28. Padman, L. (2005). Tide Model Driver Version 1.2: November 28, 2005. Earth \& Space Research. 13p.

29. Balai Besar Wilayah Sungai Serayu dan Opak. (2010). Profil Balai Besar Wilayah Sungai Serayu dan Opak. Dirjen Sumberdaya Air. Departemen Pekerjaan Umum. 25 p.

30. IOC.(2012). Sea Level Station Monitoring Facility : Sea Level at Cilacap Station; dalam http://iocsealevelmonitoring.org/station.php?code $=\mathrm{Ci}$ li, diakses 1 Oktober 2012 jam 14.30 WIB. 